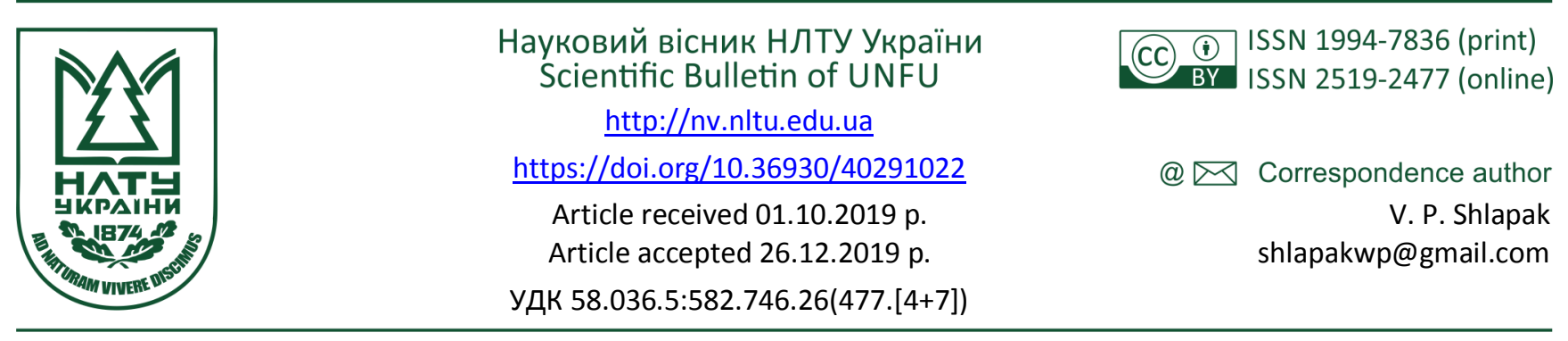

В. П. Шлапак, В. В. Мамчур, С. А. Коваль, Г. П. Іщук, С. С. Курка

Уманський нацуінальний університет садівницттва, м. Умань, Украӥна

\title{
КОМПЛЕКСНА ОЦІНКА ІНТРОДУКЦЇ̈, АКЛІМАТИЗАЦІЇ ТА ДЕКОРАТИВНОСТІ ALTISSIMA (MILL.) В УМОВАХ ПРАВОБЕРЕЖНОГО ЛІСОСТЕПУ І СТЕПУ УКРАЇНИ
}

Досліджено успішність інтродукції айланта найвищого Ailanthus altissima (Mill.) в умовах Правобережного Лісостепу і Степу України методом інтегральної числової оцінки життєздатності та перспективності інтродукції дерев на основі візуальних спостережень, який враховує найважливіші для інтродукції показники: ступінь визрівання пагонів, зимостійкість, збереження габітусу, пагоноутворювальна здатність, регулярність приросту пагонів, здатність до генеративного розвитку, способи розмноження в культурі. Визначено ступінь акліматизації інтродукованого виду A. altissima методом встановлення акліматизаційного числа. За результатами оцінки успішності інтродукції A. altissima в умовах Правобережного Лісостепу і Степу, вид віднесено до I групи перспективності, а успішність акліматизації оцінено 100 балами - у Степу та 86 балами - у Правобережному Лісостепу. Досліджено декоративність рослин A. Altissima (Mill.) в умовах Правобережного Лісостепу і Степу України. Оцінено декоративність крони, листків, суцвіть, квіток і плодів, кольору та фактури кори стовбура, гілок і пагонів. Визначено комплексну і сезонну декоративності виду A. altissima. Наведено результати дослідження комплексної та сезонної декоративності виду A. altissima, які зростають у Національному дендрологічному парку "Софіївка" НАН України, Уманському НУС, в зелених насадженнях м. Умані та Уманського р-ну, дендрологічному парку Веселі Боковеньки Кіровоградської обл., смт Чечельник Вінницької обл., м. Одеса, м. Миколаїв. Підтверджено високу декоративність A. altissima - 5 балів у Степу та 4,5 балів у Лісостепу за п'ятибальною шкалою декоративності.

Ключові слова: Ailanthus altissima (Mill.); листки; плоди; квітки; рослина.

Вступ. Показником успішності інтродукції деревних рослин $€$ їх пристосування до нових умов навколишнього середовища, тобто - акліматизація (Chmyr, Shlapak, \& Bektobekov, 1994). Одним із ефективних шляхів створення довговічних і стійких зелених насаджень $є$ залучення видів рослин з цінними декоративними властивостями (Barbarich, \& Horhot, 1952). Найвищий ступінь акліматизації рослин - їх натуралізація, рослини самостійно успішно розмножуються, входять у фітоценози і витримують конкуренцію аборигенних видів. Одним із таких декоративних інтродуцентів $\epsilon$ вид айлант найвищий Ailanthus altissima (Mill).

За твердженням М. А. Кохна (Kohno, \& Kurdyuk, 1994), існує багато шкал оцінювання успішності інтродукції рослин, у яких враховано різні фактори стійкості рослин: морозостійкість, зимостійкість, посухостійкість, здатність до регенерації, наявність плодоношення, можливість самовідновлення.

Мета дослідження - вивчити й дати оцінку успішності інтродукції, акліматизації та декоративності виду Ailanthus altissima (Mill.) в умовах Правобережного Лісостепу і Степу України.
Об'єкти та методика дослідження. Об'єктами дослідження є рослини Ailanthus altissima (Mill.) у Ботанічному саду Одеського національного університету ім. I. I. Мечникова, дендрологічному парку "Веселі Боковеньки" Кіровоградської обл., вуличних насадженнях смт Чечельник Вінницької обл., на території Національного дендрологічного парку "Софіївка" НАН України, Уманського національного університету садівництва, вуличних насадженнях м. Умань, Куяльницького лиману, в садах та парках Черкаської, Кіровоградської, Одеської та Миколаївської областей. Обстежено 255 дерев A. altissima в умовах Правобережного Лісостепу і Степу України.

Методом акліматизаційного числа М. А. Кохна (Kohno, 1994) визначено ступінь акліматизації інтродукованого виду A. altissima. Показники оцінювали візуально за 5-бальними шкалами і множили на коефіцієнт вагомості певної ознаки. Вираховували акліматизаційне число за такою формулою:

$$
A=P \cdot 6+\Gamma P \cdot 6+3 M \cdot 6+\Pi c \cdot 6,
$$

де: $P$ - показник росту; $Г Р$ - показник генеративного

Інформація про авторів:

Шлапак Володимир Петрович, д-р с.-г. наук, професор, завідувач кафедри лісового господарства. Email: shlapakwp@gmail.com Мамчур Валентина Василівна, викладач, кафедра лісового господарства. Email: mamcurvalentina@gmail.com Коваль Сергій Анатолійович, канд. с.-г. наук, доцент, кафедра лісового господарства. Email: forestry@udau.edu.ua Іщук Галина Петрівна, канд. с.-г. наук, доцент, кафедра лісового господарства. Email: forestry@udau.edu.ua Курка Світлана Сергіївна, канд. біол. наук, доцент, кафедра лісового господарства. Email: forestry@udau.edu.ua Цитування за ДстУ: Шлапак В. П., Мамчур В. В., Коваль С. А., Іщук Г. П., Курка С. С. Комплексна оцінка інтродукції, акліматизації та декоративності Ailanthus Altissima (Mill.) в умовах Правобережного Лісостепу і Степу України. Науковий вісник НЛтУ України. 2019, т. 29, № 10. C. 109-112.

Citation APA: Shlapak, V. P., Mamchur, V. V., Koval, S. A., Ischuk, G. P., \& Kurka, S. S. (2019). Complex assessment of Ailanthus Altissima (Mill.) introduction, accumulation and decorativity in the conditions of the Right-bank Forest-steppe and Steppe of Ukraine. Scientific Bulletin of UNFU, 29(10), 109-112. https://doi.org/10.36930/40291022 
розвитку; $3 м$ - показник зимостійкості; Пс - показник посухостійкості; в - коефіцієнт вагомості ознаки. Показники росту, генеративного розвитку, зимостійкості і посухостійкості оцінювали візуально за п'ятибальною шкалою. Отримані внаслідок візуальної оцінки показники множили на показник ступеня вагомості ознаки коефіцієнт вагомості. Значення коефіцієнта вагомості ознаки прийнято, зважаючи на значення цієї ознаки, необхідної для успішного перебігу інтродукційного процесу.

На основі даних шкали ступенів успішності інтродукції, запропонованої Н. А. Кохно (Kohno, \& Kurdyuk, 1994), визначали ступінь акліматизації за значеннями акліматизаційного числа:

- повна акліматизація $A=5 \cdot 2+5 \cdot 5+5 \cdot 10+5 \cdot 3=100$;

- добра акліматизація $A=4 \cdot 2+4 \cdot 5+4 \cdot 10+4 \cdot 3=80$;

- задовільна акліматизація $A=3 \cdot 2+3 \cdot 5+3 \cdot 10+3 \cdot 3=60$;

- слабка акліматизація $A=2 \cdot 2+2 \cdot 5+2 \cdot 10+2 \cdot 3=40$;

- відсутність акліматизації $A=1 \cdot 2+1 \cdot 5+1 \cdot 10+1 \cdot 3=20$.

Для визначення комплексної і сезонної декоративності виду A. altissima використано методику Н. В. Котєлової, О. Н. Виноградової (Kottelova, \& Vinogradova, 1974), Н. В. Котєлової, Н. Гречко (Kottelov, \& Grechko, 1969), В. П. Шлапака, Г. І. Музики, В. Л. Вітенка та ін. (Shlapak, Muzika, \& Vitenko, 2010). Відповідно до методики за п'ятибальною шкалою оцінено декоративність крони, листків, суцвіть, квіток і плодів, кольору та фактури кори стовбура, гілок і пагонів. Де- коративність рослин роду Ailanthus altissima визначено за такою формулою:

$$
P_{\text {cep. }}=\sum_{i=1}^{4} A_{i} P_{i} / \sum_{i=1}^{4} P_{i},
$$

де: $A_{1}$ - щомісячна оцінка архітектоніки стовбура та крони; $A_{2}$ - щомісячна оцінка декоративності листя; $A_{3}$ - щомісячна оцінка суцвіть, квіток, плодів; $A_{4}$ - щомісячна оцінка кольору і фактури кори стовбура та крони; $P_{1}$ - перевідний коефіцієнт для архітектоніки стовбура та крони, який дорівнює 4; $P_{2}-$ перевідний коефіцієнт для листя, який дорівнює $3 ; P_{3}-$ перевідний коефіцієнт для суцвіть, квіток, плодів, який дорівнює $2 ; P_{4}-$ перевідний коефіцієнт для фактури і кольору кори стовбура, який дорівнює 1.

Декоративність рослин досліджуваного виду в насадженнях оцінено за п'ятибальною шкалою декоративності О. А. Калініченка (Kalinichenko, 2000). Найголовнішим питанням $є$ оцінювання сучасного стану, загальної декоративності паркових насаджень та території загалом Шлапак В. П., О. Ю. Марно-Куца (Shlapak, \& Marno-Kutsa, 2014). Комплексну оцінку декоративних ознак деревних рослин здійснювали у балах за шкалою О. Г. Хороших і О. В. Хороших (Horoshih, \& Horoshih, 1999).

Результати дослідження. Найвища життєздатність рослин за шкалою П. І. Лапіна, С. В. Сіднєвої (Lapin, 1967). оцінюється 100 балами. Сума середніх балів є інтегральним числовим вираженням життєздатності рослини в певних умовах. Результати досліджень наведено в табл. 1.

Табл. 1. Оцінка успішності інтродукції Ailanthus altissima (за шкалою П. І. Лапіна - С. В. Сіднєвої, 1967)

\begin{tabular}{|c|c|c|c|c|c|c|c|c|c|}
\hline $\begin{array}{c}\text { Місце } \\
\text { зростання }\end{array}$ & $\begin{array}{c}\text { Ступінь що- } \\
\text { річного виз- } \\
\text { рівання па- } \\
\text { гонів }\end{array}$ & $\begin{array}{l}\text { Зимос- } \\
\text { тійкість }\end{array}$ & $\begin{array}{c}\text { Збере- } \\
\text { ження } \\
\text { габітусу }\end{array}$ & $\begin{array}{c}\text { Пагоноутво- } \\
\text { рювальна } \\
\text { здатність }\end{array}$ & $\begin{array}{c}\text { Регулярність } \\
\text { приросту па- } \\
\text { гонів }\end{array}$ & $\begin{array}{c}\text { Здатність рос- } \\
\text { лин до генера- } \\
\text { тивного роз- } \\
\text { витку }\end{array}$ & \begin{tabular}{|c|} 
Способи \\
розмно- \\
ження рос- \\
лин
\end{tabular} & $\begin{array}{c}\text { Сума, } \\
\text { бал }\end{array}$ & $\begin{array}{c}\text { Група пер- } \\
\text { спектив- } \\
\text { ності }\end{array}$ \\
\hline $\begin{array}{c}\text { м. Умань, ДП } \\
\text { "Софіївка" }\end{array}$ & 15 & 20 & 5 & 5 & 20 & 25 & 5 & 95 & I \\
\hline $\begin{array}{l}\text { смт. Чечельник } \\
\text { Вінницька обл. }\end{array}$ & 14 & 20 & 5 & 5 & 20 & 25 & 5 & 94 & I \\
\hline $\begin{array}{c}\text { ДП "Веселі } \\
\text { Боковеньки" }\end{array}$ & 20 & 20 & 15 & 5 & 25 & 25 & 15 & 100 & I \\
\hline м. Одеса & 25 & 25 & 10 & 5 & 30 & 25 & 10 & 100 & I \\
\hline м. Миколаїв & 25 & 25 & 10 & 5 & 30 & 25 & 10 & 100 & I \\
\hline
\end{tabular}

Результати оцінювання життєздатності та перспективності інтродукції вказують, що досліджуваний інтродукований вид A. altissima має високі показники життєздатності рослин і є цілком перспективним для використання його в культурі у Правобережному Лісостепу і Степу України.

Отримані внаслідок візуальної оцінки показники успішності акліматизації A. altissima показано в табл. 2.

Отже, показники життєздатності і значення акліматизаційних чисел для виду A. altissima свідчать про перспективність його інтродукції та успішність акліматизації в умовах Правобережного Лісостепу і Степу України. Рослини A. altissima в насадженнях дендрологічного парку "Софіївка" характеризуються горизонтальним ростом гілок. Молоді дерева мають широко пірамідальну крону, старі - розлогу, напіважурну. Архітектоніку стовбура і крони оцінено в чотири бали. 3 листопада по квітень дерева перебувають у безлистому стані. У цей період архітектоніка оцінюється в три бали (рис. 1).
Табл. 2. Оцінка успішності акліматизації Ailanthus altissima, інтродукованого в Правобережному Лісостепу і Степу України

\begin{tabular}{|c|c|c|c|c|c|}
\hline $\begin{array}{c}\text { Місце } \\
\text { зростання }\end{array}$ & $\begin{array}{c}\text { Рict, } \\
P\end{array}$ & $\begin{array}{c}\text { Генератив- } \\
\text { ний розви- } \\
\text { ток, } \Gamma\end{array}$ & $\begin{array}{c}\text { Зимос- } \\
\text { тійкість, } \\
3 м\end{array}$ & \begin{tabular}{|c|} 
Посу- \\
хос- \\
тійкість \\
$\Pi \Pi$ \\
\end{tabular} & $\begin{array}{l}\text { Аклі- } \\
\text { матиза- } \\
\text { ційне } \\
\text { число }\end{array}$ \\
\hline \multicolumn{6}{|c|}{ Лісостеп } \\
\hline м. Умань & 4 & 4 & 4 & 5 & 86 \\
\hline $\begin{array}{l}\text { смт. Чечельник } \\
\text { Вінницька обл. }\end{array}$ & 4 & 4 & 4 & 5 & 86 \\
\hline $\begin{array}{c}\text { Дендрологіч- } \\
\text { ний парк "Ве- } \\
\text { селі Боковень- } \\
\text { ки" }\end{array}$ & 5 & 5 & 5 & 5 & 100 \\
\hline \multicolumn{6}{|c|}{ Степ } \\
\hline м. Одеса & 5 & 5 & 5 & 5 & 100 \\
\hline м. Миколаїв & 5 & 5 & 5 & 5 & 100 \\
\hline
\end{tabular}




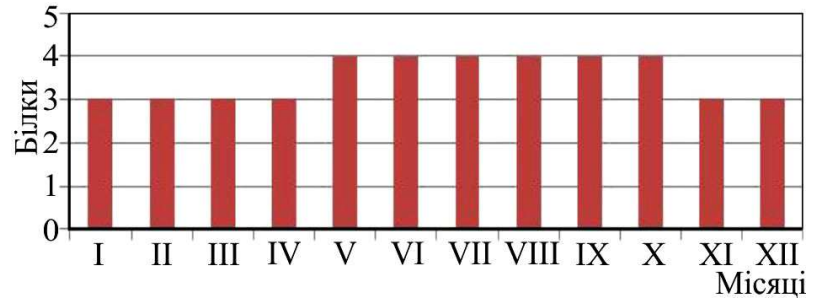

Рис. 1. Сезонна динаміка архітектоніки стовбура і крони А. altissima в дендропарку "Софіївка"

Листки A. altissima складні, непарноперисті, пальмоподібні (як у перистих пальм), дуже великі, завдовжки до $60 \mathrm{~cm}$, а у дорослих екземплярів - навіть до 1 м. Листки $з$ 13-25 листочків, яйцеподібноланщетних, голих, знизу сизуватих, завдовжки 7-12 см, з 2-4 великими тупуватими зубами біля основи. У весняний період, під час розпускання, листя має червонуватий відтінок, але 3 часом колір стає темно-зеленим. Найефективніший вигляд листки мають, коли набувають максимального розміру і кольору. Декоративність листків зберігається до листопаду (від травня до кінця жовтня), оцінено в п'ять балів.

Квітки у A. altissima дрібні, жовтувато-зелені у великих волотях, завдовжки 10-20 см. Чоловічі квітки мають неприємний запах. Квітування дерев розпочинається наприкінці травня і триває близько місяця. Декоративність квіток оцінено в 3,5-4 бали. Плоди $A$. altissima - крилатки спірально скручені 3 однією розташованою в центрі насіниною. Їх колір змінюється від зеленувато-жовтого до червонувато-коричневого, зібрані у суцвіття завдовжки 10-20 см. Надають дереву декоративного вигляду майже цілий рік.

Висока декоративність відзначається в період дозрівання плодів зі серпня по жовтень. У цей період крилатки набувають яскраво-червоного кольору. На одному суцвітті бувають різні відтінки кольору - від жовтозеленого до яскраво-червоного. Упродовж зими частина залишається на дереві. Декоративність дерев 3 плодами оцінюємо в 5 балів від серпня до кінця жовтня (рис. 2).

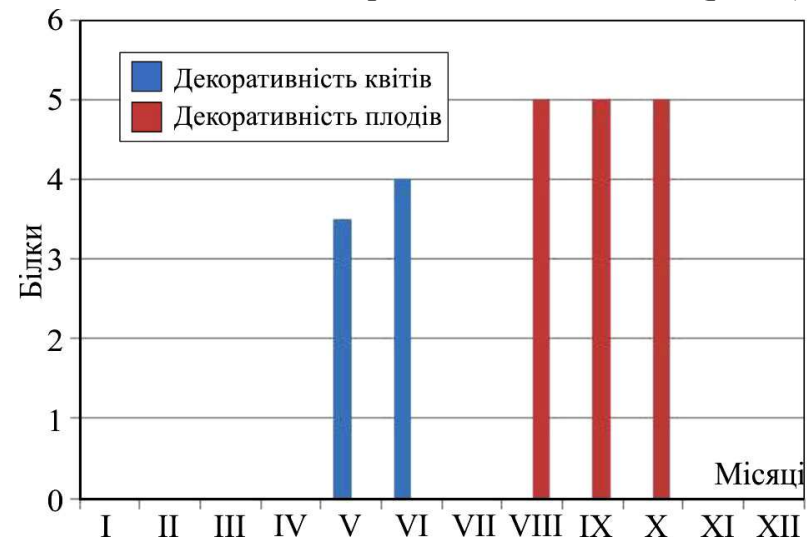

Рис. 2. Сезонна динаміка декоративності квітів та плодів А. altissima

Стовбур A. altissima прямий, циліндричний, покритий темно-сірою корою. 3 віком на ньому утворюються ромбоподібні тріщини. Декоративність стовбура, гілок та пагонів за фактурою кори та кольором оцінено в чотири бали. Молоді гілки зеленого кольору з короткими волосинками. Старі гілки стають червонувато-коричневого забарвлення і мають великі листкові рубці у формі серця $з$ округлою брунькою на верхівці.
Розрахунки динаміки декоративності дерев $A$. altissima впродовж року для кожного місяця наведено в табл. 3.

Табл. 3. Декоративність Ailanthus altissima впродовж року (2014-2017 pp.)

\begin{tabular}{|l|l|l|l|l|l|l|l|l|l|l|l|}
\hline \multicolumn{10}{|c|}{ Місяць } \\
\hline I & II & III & IV & V & VI & VII & VIII & IX & X & XI & XII \\
\hline \multicolumn{10}{|c|}{ Декоративність, балів } \\
\hline 3,4 & 3,3 & 3,3 & 3,5 & 4,3 & 4,5 & 4,5 & 4,5 & 4,5 & 4,3 & 3,5 & 3,3 \\
\hline
\end{tabular}

На основі отриманих результатів сумарний річний показник декоративності A. altissima свідчить про високу декоративність рослин цього виду. Для визначення комплексної та сезонної декоративності використано методику О. Г. Хороших. Візуально враховували архітектоніку стовбура, крону, листя, квіти, плоди. Наведені результати оцінювання дають змогу оцінити рослину, враховуючи всі морфологічні ознаки і фактори, які впливають на іiі ріст та розвиток (рис. 3).

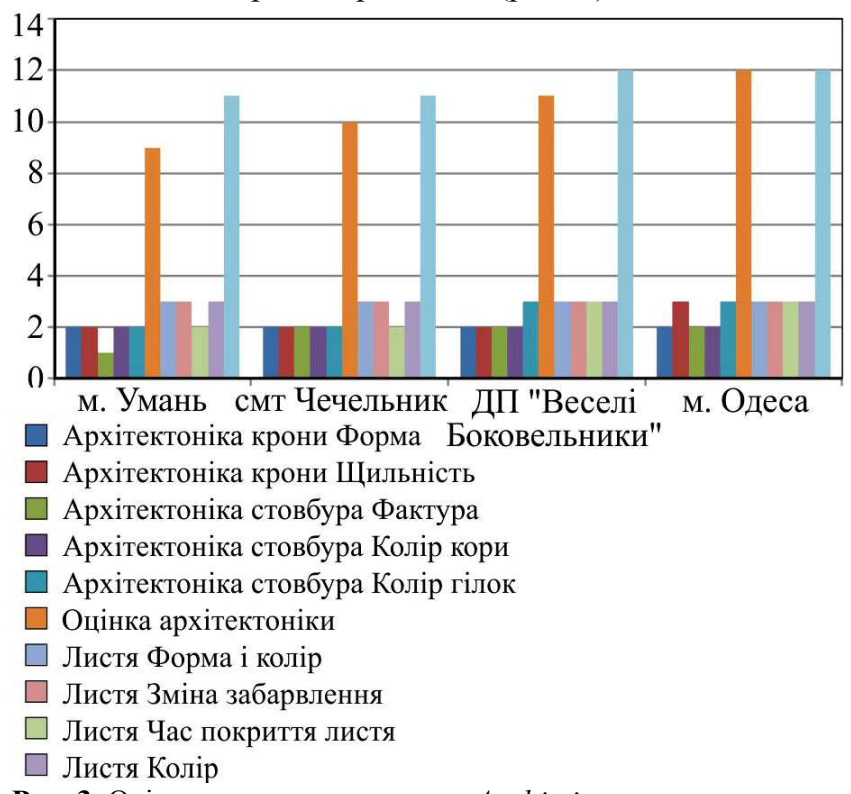

Рис. 3. Оцінка декоративних ознак A. altissima

Загальна оцінка комплексної та сезонної декоративності за шкалою О. Г. Хороших (1999) A. altissima, інтродукованого в Правобережному Лісостепу України, становила 34-35, а в Правобережному Степу України 37-38 бали.

\section{Висновки:}

1. За результатами оцінювання успішності інтродукції $A$. altissima в умовах Правобережного Лісостепу і Степу України, вид віднесено до I групи перспективності, а успішність акліматизації оцінено 100 балами в Степу України та 86 балами - у Правобережному Лісостепу, що свідчить про успішний перебіг інтродукційного процесу.

2. Підтверджено високу декоративність A. Altissima - 5 балів - у Степу та 4,5 балів - у Лісостепу за п'ятибальною шкалою декоративності.

3. Сезонна динаміка декоративності A. altissima, інтродукованого в Правобережному Лісостепу України, становила 34-35 балів, а в Степу - 37-38 балів.

\section{References}

Barbarich, A. I., \& Horhot, A. Ya. (1952). Planting of populated areas. Kyiv: Publishing of Architecture of the USSR, 362 p. [In Ukrainian]. 
Chmyr, A. F., Shlapak, V. P, \& Bektobekov, V. P. (1994). Protection of the natural environment. Kyiv: Libid, 240 p. [In Ukrainian].

Gudzenko, T. G., \& Ganzha, L. O. (1985). Ornamental gardening and garden construction, $182 \mathrm{p}$. [In Ukrainian].

Horoshih, O. G., \& Horoshih, O. V. (1999). Scale of integrated assessment of decorative signs of tree plants. Scientific Bulletin of UNFU: Research, Protection and Enrichment of Biodiversity, 9(9), 300-306. [In Ukrainian].

Kalinichenko, O. A. (2003). Decorative dendrology. Kyiv: Higher School, 199 p. [In Ukrainian].

Kalinichenko, O. A. (2006). Methodical instructions for studying discipline Dendrology. Kyiv: NNK NAU, 46 p. [In Ukrainian].

Kohno, N. A., \& Kurdyuk, A. M. (1994). Theoretical bases and experience of introduction of tree plants in Ukraine. Kyiv: Scientific Opinion, 185 p. [In Ukrainian].

Kottelov, N., \& Grechko, N. (1969). Assessment of decoration. Floriculture, 10, 11-12. [In Ukrainian].

Kottelova, N. V., \& Vinogradova, O. N. (1974). Estimation of decorative nature of trees and shrubs by seasons of the year. Physiology and plant selection and gardening of cities, (pp. 32-44). Moscow: MMLTI Yield 51. [In Ukrainian].
Lapin, P. I. (1967). Seasonal rhythms of the development of tree plants and its importance for introducing. Bulletin of the Main Botanical Garden, 65, 13-18. [In Ukrainian].

Laptev, O. O. (2001). Introduction and acclimatization of plants with the basics of planting greenery. Phytocenter Center, 128 p. [In Ukrainian].

Rusanov, F. N. (1955). Trees and shrubs of the Botanical Garden of the Academy of Sciences of the Uzbek SSR. Tashkent: Publishinghouse of the Academy of Sciences of the UzSSR, 342 p. [In Ukrainian].

Shlapak, V. P., \& Marno-Kutsa, E. Yu. (2014). Criteria for a comprehensive assessment of the present state and preservation of the historical parks of Cherkasy region. Electronic scientific journal " $F o-$ restry and gardening", 5. Retrieved from: http://ejournal.studnubip.com/zhurnal-5/ukr/shlapak-v-p/. [In Ukrainian].

Shlapak, V. P., Muzika, G. I., Vitenko, V. A., Marno, L. I., \& Gonchar, N. O. (2010). Methods of estimation of the aesthetic state of the age-old tree plantations of the historical part of the national dendropark "Sofiyivka" of the National Academy of Sciences of Ukraine. Scientific Bulletin of UNFU, 20(6), 8-13. [In Ukrainian].

V. P. Shlapak, V. V. Mamchur, S. A. Koval, G. P. Ischuk, S. S. Kurka

Uman National University of Horticulture, Uman, Ukraine

\section{COMPLEX ASSESSMENT OF AILANTHUS ALTISSIMA (MILL.) INTRODUCTION, ACCUMULATION AND DECORATIVITY IN THE CONDITIONS OF THE RIGHT-BANK FOREST-STEPPE AND STEPPE OF UKRAINE}

The success of the introduction of A. altissima (Mill.) in the conditions of the Right-bank Forest-steppe and steppe of Ukraine is investigated using the method of integral numerical estimation of the viability and perspective of the introduction of trees on the basis of visual observations, and also the promise of introduction by the method which takes into account the most important for introducing indicators such as the degree of maturation of shoots, winter resistance, conservation habitus, spin-forming ability, the regularity of the growth of shoots, the ability to generative development, and the way of reproduction in culture. The degree of acclimatization of the introduced species of $A$. altissima by the acclimatization number by M. A. Kokhna is determined, defining the degree of acclimatization by the value of the acclimatization number. We have reveiled that $A$. altissima plants in plantations are characterized by horizontal growth of branches. Young trees are found to form broad pyramidal crowns, old trees are determined to form delusional, semi-voluminous ones. The decorative character of A. altissima plants in the conditions of the Right-bank Forest-steppe and Steppe of Ukraine is investigated. The decoration of crowns, leaves, inflorescences, flowers and fruits, colour and texture of the trunk cortex, branches and shoots has been estimated. The complex and seasonal decorativeness of $A$. altissima species was determined. The results of the study of the complex and seasonal decorative form of A. altissima species growing in the National Dendrological Park "Sofiyivka" of the National Academy of Sciences of Ukraine, the Uman National University of Horticulture, in green plantations of Uman and Uman District, Vesely Bokovenki Dendrological Park of Kirovograd Region, Chechelnik Town of Vinnitsa Region, and the cities of Odessa and Mykolayiv. Thus, according to the results of the assessment of the success of $A$. altissima introduction in the conditions of the Right-bank Forest-steppe and Steppe of Ukraine, the species is in the forester perspective group, and the success of its acclimatization is estimated at 100 points in the Ukrainian Steppe and 86 points in the Right-bank Forest-steppe, indicating the success of full completion of the introduction process. The high curative qualities of $A$. altissima have been confirmed (5 points in the Steppe and 4.5 points in the Forest-steppe on a five-point decorative scale). It has been established that the decorative character of A. altissima, introduced in the Right-bank Forest-steppe of Ukraine, reached 34-35 points, and 37-38 points in the Steppe zone. Based on the detailed research, the authors studied and assessed the success of the introduction, acclimatization and decorative character of the species A. altissima in the conditions of the Right-bank Forest-steppe and Steppe of Ukraine.

Keywords: Ailanthus altissima (Mill.); leafage; fruits; flowers; plant. 